\title{
Records of the Northern Flying Squirrel in Saskatchewan
}

by D. Wayne Davis, University of Arkansas, Fayetteville, Arkansas

A life history study of the northern flying squirrel, Glaucomys sabrinus (Shaw), was begun in July, 1960, at the University of Saskatchewan and was concluded in June, 1963*. Specimens were collected from several areas where flying squirrels have previously not been reported. Squirrels were trapped at Candle, Christopher, Cree, Emma, Potato and Waterhen Lakes and at Lac la Ronge and Stony Rapids. These specimens have been placed in the biology museum at the University of Saskatchewan. Trappers and conservation officers have assured me that flying squirrels also are found at Dore and Forster Lakes.

The flying squirrel has previously

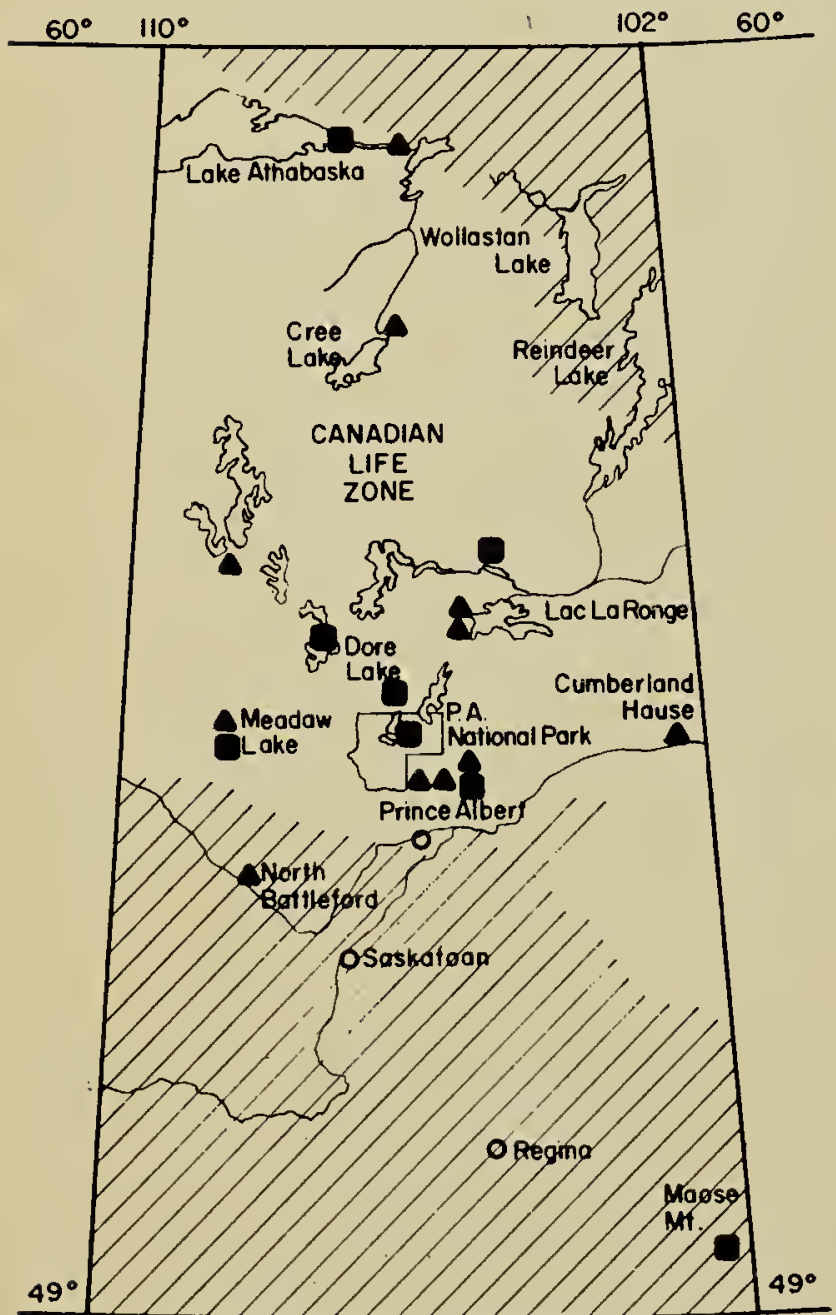

DISTRIBUTION RECORDS OF THE NORTHERN FLYING SQUIRREL IN SASKATCHE WAN

- Record of Specimen

Report of Occurrence

\footnotetext{
* This study was supported by the National Research Council of Canada and the Institute for Northern Studies.
}

been reported from Emma Lake (Banfield, 1941), Meadow Lake, Moose Mountain, Frince Albert National Park and Birchbark and Harper Lakes (Soper, 1946, 1952, 1961), Buffalo Narrows and Lorado [Beaverlcdge Lake] (Beck, 1958, 1962), Cumberland House (Hall and Kelson, 1959), and Battleford (isealy, 1961). To my knowledge specimens have been collected (prior to the present study) only from Battleford, Buffalo Narrows, Cumberland House and Emma Lakes. All other reports of occurrences have came from information supplied by residents of the particular area. The distribution map shows that only one flying squirrel (the specimen from Battleford) has been collected outside the Canadian Life Zone.

During the winter of 1962 I observed, on three different trips, a male and female flying squirrel on Fairy Island in Emma Lake. Each night the squirrels entered the cabin and made sleeping almost impossible. Once I awoke with a flying squirrel standing on my face. They were not disturbed by a gas lantern and readily took food from my hand. The female drank apple juice from a can I held the first night I saw her. The squirrels carried outdoors the food they did not immediately eat but returned in a few minutes for more food.

Their winter nest was probably in a hollow snag or woodpecker hole near the cabin. Flying squirrels often build nests in cabins during the winter but move outside in early spring. Cottage owners might attract flying squirrels by providing food and nesting sites. Feeding boxes can be baited with nuts, sunflower seeds, corn, peanut butter and fruits. In the present study, flying squirrels were caught only in areas where nesting sites were in abundance, so all old snags and hollow trees should be left standing. Les Kerr of Saskatoon has had flying squirrels utilize nest boxes near his cabin at Emma Lake. Mr. Kerr places a nail keg inside a large nest box. For extra warmth insulating material and cotton for bedding may be added to the nest box. 
